\title{
Quoth the Doctors
}

\section{Section Editor}

Anne W. McCammon,

MD, FAAN

Katherine Noble Allen

Correspondence to

Ms. Allen:

allenkn@dukes.jmu.edu
The glia make a myelin sheath,

(a blanket with axon beneath).

This helps the neuron act with haste, until by MS it's laid waste.

Could MS come from Mom or Dad; perhaps some virus that was had; or vitamin D that was too low? Quoth the doctors, "We don't know."

Amazing is the MRI!

It shows us what and where and why. In seeing deep within our heads, it helps reveal the good in meds and diagnoses with its view.

With all an MRI can do, there's sure to be a cure, I bet! Quoth the doctors, "No, not yet."

Imagine now this scary scene: of plaques and lesions unforeseen; of limbs not feeling, with no might; of words forgot, and double sight. MS can be a tragedy, or just a worry none can see. So being sure not to delude, Quoth the doctors, "Some are screwed."

But wait, let's not succumb to fear! The answers could be very near. We'll study, work, and concentrate on trying to remyelinate. With MS cured - and once again our neurons wrapped in myelin we'll solve the riddles we explore. Then doctors shall quoth "Nevermore!" 


\section{Neurology}

Quoth the Doctors

Katherine Noble Allen

Neurology 2013;80;687

DOI 10.1212/WNL.0b013e318281cd15

This information is current as of February 11, 2013

\section{Updated Information \&} Services

Subspecialty Collections

Permissions \& Licensing

Reprints including high resolution figures, can be found at: http://n.neurology.org/content/80/7/687.full

This article, along with others on similar topics, appears in the following collection(s):

MRI

http://n.neurology.org/cgi/collection/mri

Multiple sclerosis

http://n.neurology.org/cgi/collection/multiple_sclerosis

Information about reproducing this article in parts (figures,tables) or in its entirety can be found online at:

http://www.neurology.org/about/about_the_journal\#permissions

Information about ordering reprints can be found online:

http://n.neurology.org/subscribers/advertise

Neurology ${ }^{\circledR}$ is the official journal of the American Academy of Neurology. Published continuously since 1951, it is now a weekly with 48 issues per year. Copyright @ 2013 American Academy of Neurology. All rights reserved. Print ISSN: 0028-3878. Online ISSN: 1526-632X.

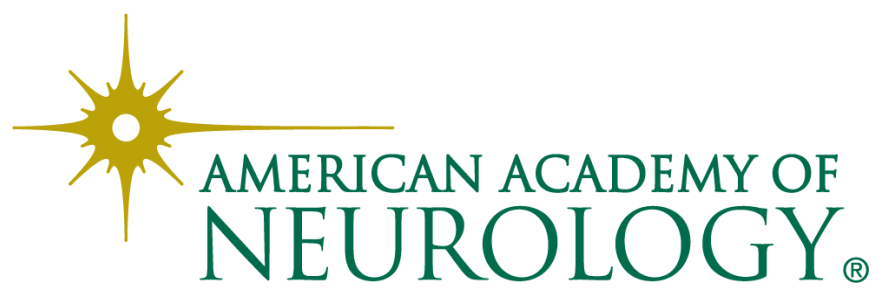

